\title{
The history of the formation of international organizations in the world
}

\section{INTRODUCTION}

The main source of the emergence of organizational trends in international relations was the presence of various types of threats and challenges. To meet them, the efforts of more actors were needed. These challenges were mainly related to the threat to the security of the enemy or insufficient own forces for the intended expansion, which prompted the search for allies. Along with the development of civilization, other problems arose, especially related to economic and technical development. ${ }^{1}$

These difficulties influenced the process of shaping new entities in the international arena in the form of international organizations. Their formation and development was conditioned by many factors. One of the basic factors was the increase in international economic turnover, the development of which depended on the achievement by the societies of a given subregion, region or continent of a high degree of technical progress. ${ }^{2}$ The objective reasons for the development of international organizations are, above all, the progress of technology and the strengthening of international relations, which have led to the emergence and increasing interdependence of states in many areas, including in communication and communication, economic relations, social issues, science and technology, environmental protection, and above all in political matters and peace-keeping. ${ }^{3}$

${ }^{1}$ M. Proczek, Międzyrządowe organizacje międzynarodowe. Finansowanie działalności przyktad ONZ i MFW, Warszawa 2013, pp. 40-41.

${ }^{2}$ Z.M. Doliwa-Klepacki, Encyklopedia organizacji międzynarodowych, Warszawa 1997, p. 49.

3 W. Góralczyk, S. Sawicki, Prawo międzynarodowe publiczne w zarysie, Warszawa 2006, p. 292. 
The aim of this study is to show the genesis of the formation of international organizations as separate entities in international relations on the legal-comparative level. The use of the dogmatic and comparative methods allows for a better understanding of the will of the founders of organizations (founding countries) in terms of membership and comparing them in terms of the normative methods used.

\section{THE GENESIS OF THE ESTABLISHMENT OF INTERNATIONAL ORGANIZATIONS IN THE WORLD}

The precursors of the creation of the first international organizations appeared in antiquity. During this period, the then society of Greece was divided into many small states, which were characterized by sovereignty and autonomy, which favored the formation of interdependence of states, whose task was to cooperate with each other. $^{4}$

The Greek states created religious and political organizations that were established to protect the common religious cult. They included amphithets ${ }^{5}$ and koinons. ${ }^{6}$ The largest, numbering 12 city-states, was the Delphi-Thermopylae Amphixion with its seat in Delphi (in the Temple of Apollo) and Thermopylae (in the Temple of Demetry). Meeting twice a year, the assembly of members elected a 24-member college of hieromnemon. Its activity was financed from gifts sent to churches, and the administrative services were performed by priests. Political and military organizations were also created in the form of offensive symmachias ${ }^{7}$ and epimachy, ${ }^{8}$ which carried out defense tasks. Among the symmachias, the largest

${ }^{4}$ Z.M. Doliwa-Klepacki, Encyklopedia ..., s. 49.

5 Amfiktionias were international organizations aimed at protecting places of religious worship. Originally, their activity was focused on the organization of religious ceremonies, but as a result of the gradual accumulation of material goods in temples through sacrifices, there was a need to protect and dispose of their resources. See A. Świstak, Początki instytucjonalizacji wspótpracy międzynarodowej w starożytnej i średniowiecznej Europie, "Studenckie Zeszyty Naukowe" 2017, Vol. XX, No. 34, p. 57.

${ }^{6}$ Koinon were international organizations in ancient Greece of a political nature. Their activity focused on the protection of the political interests of the Greek policies within the community. Ibidem.

${ }^{7}$ Symmachie was a form of cooperation of the Greek states in the form of military alliances serving defense and attacks in the event of a threat from the enemy. They were defensive and offensive in nature. See P.J. Rhodes, Ancient Athens: Democracy and Empire, "European Review of History" 2009, Vol. 16, No. 2, p. 204.

${ }^{8}$ Epimachie was a form of cooperation between Greek states aimed at protecting common interests in the event of any attacks by the enemy. Such alliances were only defensive in nature. Ibidem, s. 204. 
was the Peloponnesian League and the 300-nation Athens-Delilian League (known as the Sea League). ${ }^{9}$

The cooperation of the policies was also realized in the form of isopolitie or sympolitie. Isopolities were entities that brought together states on the basis of international treaties or mirror acts of internal law. Their members did not give up their independence, and there was full equality among citizens. In turn, sympolities were a form of international cooperation among Greek states - complex states. Established in the $4^{\text {th }}$ century BC they were created on the basis of international agreements. The largest of them were the Achaean and Aetolian confederations. Both of these forms of cooperation between Greek states were created on the basis of international agreements, but did not themselves create a new entity in international relations. ${ }^{10}$

It should be noted that during this period three unions were also important: the Hellenic Union - established to counter the Persian threat, the Athenian Maritime Union - grouping a large number of Greek states with a democratic system, and the Corinthian Union - covered by the protectorate of Macedonia and serving to preserve peace in Hellas in during the planned attack on Persia. ${ }^{11}$

The development of the international community in the following years entailed the need to create, recognize and sanction more and more perfect forms of cooperation between the countries that made up this community in a given era. The loose, limited to the essential, ties between the states belonging to the medieval international community did not yet require the regulation of international life in a broader scope. ${ }^{12}$ During this period, organizational tendencies found expression in the concept of Christian universalism with the pope and the emperor in the center (or the emperor and the pope, because it was the rank and mutual relations that were disputed). An important element of the system were councils, great meetings of clergy and laity, which performed important political (apart from religious) functions. ${ }^{13}$ Although it was not a typical form of inter-state cooperation, even then it was possible to observe how important it was to combine several entities in order to implement common assumptions, which for each individual member were very difficult to achieve.

9 J. Menkes, A. Wasilkowski, Organizacje międzynarodowe. Prawo instytucjonalne, Warszawa 2017 , pp. 91-92.

${ }^{10}$ Ibidem, p. 92.

${ }^{11}$ E. Łaźniewska, S. Piotrowski, M. Zajęcki, Istota, geneza, rola i funkcje organizacji międzynarodowych [in:] E. Łaźniewska, P. Deszczyński (eds.), Kompendium wiedzy o organizacjach międzynarodowych, Warszawa 2011, p. 32.

${ }_{12}$ G. Grabowska, Obserwatorzy państw w powszechnych organizacjach międzynarodowych, Warszawa 1978, p. 5.

${ }_{13}$ J. Menkes, A. Wasilkowski, Organizacje międzynarodowe..., p. 94. 
An example of the institutionalization of interstate cooperation in the Middle Ages was the League of Lombardy and the League of Italy. ${ }^{14}$ The Hanseatic unions, i.e. the Hanseatic League and the Hanseatic League, are considered to be the precursors of international economic organizations at that time. ${ }^{15}$ They connected mainly port cities. In the period of its greatest prosperity (the $16^{\text {th }}$ century), these unions gathered around 60 European cities. Every few years, general meetings of members were held, decisions were made by a majority of votes. Their subjects were most often activities aimed at obtaining new port and commercial privileges and facilitating mutual trade. ${ }^{16}$

The period in which the modern international community was formed falls on the $17^{\text {th }}$ century. ${ }^{17}$ At that time, the Treaty of Westphalia of 1648 was of great importance, which consisted of two acts: instrumentum pacis Osnabrugense, i.e. peace between the German Reich and Sweden, and instrumentum pacis Monastreiense, i.e. peace between the Reich and France. The special meaning of this document was that it recognized the equality of Christian states. As Zygmunt Cybichowski notes, "only since the Peace of Westphalia does he know the principle of tolerance, which was preceded by several hundred years by national law, which still adheres to the principle: cuius regio, eius religio, that is, the ruler of the state could rewrite his religion to his subjects." 18 This treaty proclaimed the principle of sovereignty and equality of states, which is a necessary condition for the establishment of an international community. ${ }^{19}$ The community of states that was developing in Europe, basing their relations on international law, formed a system. It was an elite system that developed through the accession of new states and the recognition of their international legal subjectivity. Hence the concept of membership of the international community, which was initially available only to European countries, then to countries (the effect of political development in the Western Hemisphere), and finally to countries defined as civilized (due to joining the community of non-Christian countries, e.g. Japan and the Ottoman Empire). ${ }^{20}$

Trends in increasing the diversity of international organizations were manifested in three periods that can be considered stages in the evolution of international organizations. The first one covers the $19^{\text {th }}$ century and the beginning of the $20^{\text {th }}$ century, until the end of World War I. The second period is the interwar period,

${ }^{14}$ S. Bielański, Koncepcja Padanii na przełomie XX i XXI wieku, "Przegląd Geopolityczny" 2016, No. 18, p. 10.

${ }^{15}$ M. Kostrzewska, Miasto europejskie na przestrzeni dziejów. Wybrane przykłady, Gdańsk 2013, pp. 71-72.

${ }_{16}$ J. Menkes, A. Wasilkowski, Organizacje międzynarodowe..., p. 94.

17 Ibidem, p. 97.

18 Z. Cybichowski, System prawa międzynarodowego, Warszawa 1923, p. 39.

19 E. Łaźniewska, S. Piotrowski, M. Zajęcki, Istota, geneza, rola .., p. 32.

${ }^{20}$ J. Menkes, A. Wasilkowski, Organizacje międzynarodowe..., pp. 97-98. 
and the third period - modern times, initiated by conferences from World War II, during which the statutes of new universal organizations were developed and adopted. ${ }^{21}$

An important event that influenced the cooperation of the international community at that time was the Congress of Vienna held in 1814-1815 and the new forms of international cooperation ${ }^{22}$ that emerged as a result of it, the formation of the first world associations after the establishment of the International Telegraphic Union in $1865,{ }^{23}$ and the Hague Conferences of 1899 years and 1907, which for the first time brought together all the then countries of the world. ${ }^{24}$

The first attempts to create an institutional framework for the organizational processes of the international community were made by the Congress of Vienna in 1814, which was one of the most crowded gatherings in the history of Europe. For the first time, the institution of a congress not only served to make peace, but was also a place of joint deliberations on the reorganization of European affairs after the twenty-year war period. ${ }^{25}$

An important organizational attempt that was made by Austria, Prussia and Russia in connection with the Congress of Vienna was the creation of the Holy Alliance, which was aimed at protecting the dynastic and legitimist order and the right to intervene in the event of their violation, including military actions. It was a reactionary organization whose main task was to maintain and strengthen the political system established by the Congress of Vienna. ${ }^{26}$

It is impossible not to mention here the Hague Conferences of 1899 and 1907, which were convened in order to strengthen the peaceful foundations of relations between states. Their great success was the establishment of a catalog of measures

${ }^{21}$ I. Popiuk-Rysińska, Organizacje międzynarodowe. Zarys problematyki [in:] S. Parzymies, I. Popiuk-Rysińska (eds.), Polska w organizacjach międzynarodowych, Warszawa 2002, p. 22.

${ }^{22}$ The Congress of Vienna is also an indication of the breakthrough of the principle of the balance of power. The prior and further development of international relations has shown that the balance of power and balancing the interests of the members of the international community is a necessary condition for its institutional organization. In the $19^{\text {th }}$ century, this state of affairs was metaphorically referred to as "the concert of Europe." See E. Łaźniewska, S. Piotrowski, M. Zajęcki, Istota, geneza, rola .., p. 32 .

${ }^{23}$ As a result of the merger of the International Telegraphic Union that had existed since 1865 and the International Radiotelegraphic Union established in 1906, the International Telecommunications Union was established in 1932, which began its activity on January 1, 1934. See Z.M. Doliwa-Klepacki, Encyklopedia organizacji międzynarodowych, Warszawa 1975, p. 353; cf. J. Machowski, Organizacje międzynarodowe, Warszawa 1956, pp. 132-133.

24 J. Menkes, A. Wasilkowski, Organizacje międzynarodowe..., p. 98.

${ }^{25}$ K. Wolfke, Wielkie i małe państwa na Kongresie Wiedeńskim, "Państwo i Prawo" 1949, No. 4 , p. 30 .

${ }^{26}$ J. Machowski, Organizacje..., p. 17. 
for the peaceful settlement of international disputes, which were confirmed in the Convention for the peaceful settlement of international disputes. ${ }^{27}$

The nineteenth century was a period when particularistic organizations of a regulatory nature appeared. They were the so-called international river commissions (Central Rhine Navigation Commission or the European Danube Commission). Somewhat later, states began to create universal unions (unions) intended to be a form of more effective implementation of their interests in specific areas related to economic turnover. They were the so-called special or administrative unions (International Telegraphic Union or Universal Postal Union (UPU). ${ }^{28}$

Three important initiatives taken at the Paris peace conference were of particular importance. These were in particular: the creation of the League of Nations (LN), ${ }^{29}$ the establishment of the Permanent Court of International Justice (STSM) ${ }^{30}$ and the establishment of the International Labor Organization (ILO). ${ }^{31}$

The League of Nations, established on June 28, 1919, was an international organization that was to ensure peace and post-war order. "Idealistic visions of its functioning assumed that the "old order" was to belong to the past. It was to be replaced by a new "beautiful world" built on the smoking ruins of an old civilization. The small nations as well as the great ones were to experience justice. The powers were to disarm and remain in the world peace league system." ${ }^{32}$ The League of Nations was an organization that set itself tasks and goals that in earlier years were articulated by various, dispersed unions and institutions. It is also worth noting that it was the first international organization in history to cover the entirety of international life. ${ }^{33}$

According to Art. 14 of the League of Nations Covenant and on the basis of the protocol of 1920, the first international court in the history of interstate relations

27 Z.B. Rudnicki, Międzynarodowe komisje badawcze w nowoczesnym systemie pokojowego rozwiązywania sporów międzynarodowych, "Zeszyty Prawnicze” 2011, No. 11(3), pp. 287-288.

${ }_{28}$ C. Mik, Fenomenologia regionalnej integracji państw. Studium prawa międzynarodowego, vol. I, Warszawa 2019, p. 5.

${ }^{29}$ Pakt Ligi Narodów z dnia 28 czerwca 1919 roku [in:] K. Kocot. K. Wolfke (eds.), Wybór dokumentów do nauki prawa międzynarodowego, Wrocław - Warszawa 1969, pp. 47-58; Dz. U. 1920, Nr 35, poz. 200 [Journal of Laws 1920, No. 35, item 200].

${ }^{30}$ Protokół podpisania Statutu Stałego Trybunału Sprawiedliwości Międzynarodowej, przewidzianego w art. 14 Paktu Ligi Narodów z dnia 16 grudnia 1920 roku, Dz. U. 1923, Nr 106, poz. 839 ze zm. [Journal of Laws 1923, No. 106, item 839 as amended].

${ }^{31}$ Konstytucja Międzynarodowej Organizacji Pracy z dnia 9 października 1946 roku [in:] S. Hubert (ed.), Zbiór statutów i regulaminów organizacji międzynarodowych. Organizacje wyspecjalizowane ONZ, vol. 2, part 1, Warszawa 1966, pp. 63-88; Dz. U. 1948, Nr 43, poz. 308 ze zm. [Journal of Laws 1948, No. 43, item 308 as amended]; J. Menkes, A. Wasilkowski, Organizacje miedzynarodowe..., p. 114.

32 W. Balcerak, Dzieje Ligi Narodów, Warszawa 1969, p. 26.

${ }^{33}$ S. Sierpowski, Geneza Ligi Narodów, “Dzieje Najnowsze” 1999, No. 31(1), p. 19. 
(not counting the Central American Tribunal operating in the years 1907-1917) was established under the name of the Permanent Court of International Justice in The Hague. It started its activity in 1922. Its creation and activity were a breakthrough in international law. The project to create an international court during the Second Hague Peace Conference in 1907 was unsuccessful. The successful establishment of the STSM in 1930 made it possible for states to submit their disputes to an international body, which ruled legally on the basis of international law. ${ }^{34}$

The Commonwealth of Nations (WN), established under the name of the British Commonwealth of Nations $(\mathrm{BWN})^{35}$ under the Statute of Westminster of December 11, 1931, was of significant importance. ${ }^{36}$ It is an institutionalized form of cooperation between the states of the former British Empire. ${ }^{37} \mathrm{~A}$ large number of governmental and non-governmental organizations operate under the auspices of the Community, contributing to the improvement of cooperation between the Member States. They are similar in nature to specialized organizations and perform for the Community similar functions to those performed by its specialized organizations for the United Nations. ${ }^{38}$ The Commonwealth of Nations consists of 54 countries located in Africa, Asia, North America, South America, Europe and the Pacific. ${ }^{39}$

The International Labor Organization, established on October 9, 1946, was the only one to deal with important social problems and the increase in unemployment. The aim of its activity was not only to improve working conditions, but also the standard of living. She also postulated the protection of values such as the dignity and equality of every human being. The ILO Constitution also provided for the protection of certain personal freedoms, in particular of expression and association. The aim of the organization was not only to protect employees, but also to care for increasing general welfare. ${ }^{40}$ The ILO's normative output is enormous, as

${ }^{34}$ K. Skubiszewski, Bohdan Winiarski jako sędzia międzynarodowy, "Ruch Prawniczy, Ekonomiczny i Socjologiczny” 1999, No. 3, p. 2.

${ }^{35}$ The term "Commonwealth of Nations" has replaced the previous term "British Commonwealth of Nations". This in turn replaced the previously functioning concept of "British Empire," definition available at: https://encyklopedia.pwn.pl/haslo/Wspolnota-Narodow;3998422.html [accessed on 20.11.2019].

${ }^{36}$ Statut Westminsterski z dnia 11 grudnia 1931 roku [in:] L. Gelberg, Prawo międzynarodowe i historia dyplomatyczna. Wybór dokumentów, Warszawa 1954-1960, pp. 338-343.

${ }_{77}$ S. Soroka, Rola Kanady w transformacji Imperium Brytyjskiego. Analiza stosunków kanadyjsko-brytyjskich w okresie międzywojennym, Kraków 2014, p. 163.

${ }^{38}$ E. Dynia, Charakter prawnomiędzynarodowy Brytyjskiej Wspólnoty Narodów, “Annales Universitatis Mariae Curie-Skłodowska" 1983, Vol. XXX, pp. 135-136.

${ }^{39}$ List of the countries of ILO: https://thecommonwealth.org/member-countries [accessed on 23.11.2019].

${ }^{40}$ A. Michalska, Ochrona praw człowieka w ramach Międzynarodowej Organizacji Pracy, "Ruch Prawniczy, Ekonomiczny i Socjologiczny" 1979, No. 3, p. 18. 
examples include the Convention on Minimum Standards of Social Security of June 28, 1952, ${ }^{41}$ or the Convention on Forced or Compulsory Labor of June 28, $1930 . .^{42}$

During World War II, the idea of establishing a new universal organization was born, the aim of which would be to maintain world peace and create a collective security system. The initial charter of the new entity was drafted at the Dumbarton Oaks conference, while the main process of creating the United Nations (UN) took place at the Big Three 'summit conference' in Yalta. During this conference, on February 3-11, 1945, the leaders of the three great powers - W. Churchill, FD Rosevelt and J. Stalin - agreed on voting rules in the UN Security Council, including the requirement for unanimity of the great powers on substantive matters, and decided to invite China and France to be the organizers of the founding conference. ${ }^{43}$ In its course, the text of the United Nations Charter (KNZ) was established, which was signed on June 26, 1945, and entered into force on October 24, 1945. ${ }^{44}$ It was supposed to be a set of the most fundamental legal norms determining the proper development of the international community reborn after World War II. ${ }^{45}$

Among the organizations established outside Europe, the Organization of American States (OAS) is of great importance. It was established in 1948 at the IX Inter-American Conference in Bogota. It brings together the countries of Latin America, the United States and Canada. The organization follows the idea of pan-Americanism. In accordance with the provisions of the Organization of American States Charter adopted on April 30, 1948 ${ }^{46}$ its purpose is to strengthen peace and security on the American continent, to strengthen cooperation in the protection of democratic values and to defend common interests, to ensure a peaceful way of settling disputes, and to jointly solve economic and social problems., politi-

${ }^{41}$ Konwencja nr 102 Międzynarodowej Organizacji Pracy dotycząca minimalnych norm zabezpieczenia społecznego z dnia 28 czerwca 1952 roku, Dz. U. 2005, Nr 93, poz. 775 [Convention No. 102 of the International Labor Organization on Minimum Standards of Social Security of 28 June 1952, Journal of Laws 2005, No. 93, item 775].

${ }^{42}$ Konwencja $\mathrm{nr} 29$ dotycząca pracy przymusowej lub obowiązkowej z dnia 28 czerwca 1930 roku, Dz. U. 1959, Nr 20, poz. 122 ze zm. [Convention No. 29 relating to Forced or Compulsory Labor of 28 June 1930, Journal of Laws 1959, No. 20, item 122 as amended].

${ }^{43}$ T. Kegel, A. Nowak, Międzynarodowe organizacje uniwersalne, regionalne i grupowa [in:] T. Łoś-Nowak (ed.), Współczesne stosunki międzynarodowe, Wrocław 1997, p. 111.

${ }^{44}$ Karta Narodów Zjednoczonych z dnia 26 czerwca 1945 roku [in:] A. Przyborowska-Klimczak (ed.), Prawo międzynarodowe publiczne. Wybór dokumentów, Lublin 2006, pp. 9-42.

${ }^{45}$ A. Henczel, Zagadnienie rewizji Karty Narodów Zjednoczonych, "Ruch Prawniczy, Ekonomiczny i Socjologiczny" 1984, No. 4, p. 135; cf. I. Popiuk-Rysińska, The Charter of the United Nations and New Challenges for International Peace and Security [in:] J. Nowakowska-Małusecka (ed.), New Challenges for International Organizations, Katowice 2016, pp. 50-58.

${ }^{46}$ Karta Organizacji Państw Amerykańskich z dnia 30 kwietnia 1948 roku [in:] K. Kocot, K. Wolfke, Wybór dokumentów..., pp. 122-133. 
cal issues, and discussing major issues emerging in the region and on the world stage. ${ }^{47}$

Western European countries, strongly weakened by the war, decided to obtain aid from the United States, fearing military threats. Their goals were focused on security and defense. In connection with the above, in 1949 the North Atlantic Treaty was concluded, on the basis of which a political and military organization in the form of the North Atlantic Treaty Organization (NATO) was created. ${ }^{48}$ It is an organization that plays an important role in the international arena, guarding the security and protection of its members and stabilizing the world's forces. It strives for development and international agreements to ensure the security of not only its members, but also other entities of international relations, such as Poland, in relation to which NATO is an extremely important ally due to the fact that it is a multilateral instrument of security policy for it. ${ }^{49}$

On the European continent, the Council of Europe, which was established on May 5, 1949 by Belgium, Denmark, France, the Netherlands, Ireland, Luxembourg, Norway, Sweden, Great Britain and Italy, became a particularly important organization that made a huge contribution to the development of Europe.$^{50}$ It was created as an expression of the search for areas of cooperation that would create the prospect of the peaceful development of European societies. The scope of its activity is wide, and only defense matters have been excluded. The CoE pays particular attention to the creation and implementation of standards relating to democracy, the rule of law and the protection of human rights. ${ }^{51}$

Parallel to the integration process in Western Europe, there was also an idea to create an international organization in Eastern Europe. The Council for Mutual Economic Assistance (Comecon) was established on the initiative and under pressure from the USSR at a conference of six states held in Moscow on January

${ }^{47}$ B. Liżewski, M. Myślińska, Mechanizm ochrony praw człowieka w systemie Rady Europy $i$ w systemie interamerykańskim: teoretyczna analiza prawnoporównawcza, "Studia Iuridica Lublinensia" 2014, No. 21, p. 106.

48 Traktat Północnoatlantycki z dnia 4 kwietnia 1949 roku [in:] A. Przyborowska-Klimczak, E. Skrzydło-Tefelska (eds.), Dokumenty europejskie, vol. I, Lublin 1996, pp. 214-216.

${ }^{49}$ M. Zając, Założenie strategiczne funkcjonowania NATO, "Horyzonty Bezpieczeństwa" 2015, No. 1(1), p. 75; cf. A. Kobieracki, Polska w NATO [in:] E. Haliżak, T. Łoś-Nowak, A. Potyrała, J. Starzyk-Sulejewska (eds.), Polska w instytucjach międzynarodowych w latach 1918-2018, Warszawa 2019, s. 577.

${ }^{50}$ Statut Rady Europy z dnia 5 maja 1949 roku [in:] A. Przyborowska-Klimczak, E. Skrzydło-Tefelska (eds.), Dokumenty europejskie, vol. II, Lublin 1999, pp. 66-72. More about Council of Europe: J. Jaskiernia, Polska w systemie Rady Europy [in:] E. Haliżak, T. Łoś-Nowak, A. Potyrała, J. Starzyk-Sulejewska (eds.), Polska w instytucjach..., p. 712.

${ }^{51}$ J. Jaskiernia, Polityczny wymiar objęcia państw Europy Środkowej $i$ Wschodniej standardami demokratycznymi Rady Europy, "Nowa Polityka Wschodnia" 2011, No. 1(1), pp. 16-17. 
5-8, 1949. Its statute was adopted in $1959 .^{52}$ The official goal of Comecon was to contribute, by combining and coordinating the efforts of the member states to deepening and improving cooperation and economic integration, the planned development of the national economy, accelerating economic and technical progress, increasing the level of industrialization, constant level of labor productivity, gradual approximation and equalization of the level of economic development and increasing the prosperity of the nations of the member countries. In essence, however, the purpose of establishing Comecon was to link the economies of the people's democracy with the economy of the USSR and their subordination to the economic interests of the USSR. ${ }^{53}$

Another organization that played an important role in European integration was the European Coal and Steel Community (ECSC), ${ }^{54}$ founded on April 18, 1951 by Belgium, France, the Netherlands, Luxembourg, West Germany and Italy. Its main goal was to create a common market for coal, iron and steel of the Member States, to modernize these sectors of the economy and to coordinate the impact on the prices of their products. The creation of the ECSC brought many economic benefits to European countries in the form of trade privileges. A positive effect was also the awareness of the possibility of finalizing the concept and integration plans. This encouraged the ECSC member states to continue their efforts to deepen economic integration. On March 25, 1957 in Rome, the ECSC countries established under two separate agreements - the so-called Of the Treaties of Rome, the European Economic Community (EEC) $)^{55}$ and the European Atomic Energy Community (Euratom).$^{56}$ Both treaties, which entered into force on January 1, 1958, were concluded for an unlimited period. ${ }^{57}$ On the basis of such developed cooperation, in December 1991, during the Maastricht summit, decisions were made that marked a turning point in the history of the three Communities. On February 7, 1992, all Member States signed the Treaty on European Union, which entered into force on November 1, 1993..$^{58}$ The Treaty established the European Union (EU), which was not a new international organization but only a new stage in cooperation between the Member States. ${ }^{59}$ At the beginning of 2007, a vision of a new revision treaty

${ }^{52}$ Statut RWPG [in:] K. Kocot, K. Wolfke (eds.), Wybór..., pp. 153-161. Dz. U. 1960, Nr 35, poz. 197 [Journal of Laws 1960, No. 35, item 197].

${ }^{53}$ E. Pawlak, A. Malkowski, Przeglą organizacji międzynarodowych, Szczecin 2006, p. 71.

${ }^{54}$ Traktat ustanawiający Europejską Wspólnotę Węgla i Stali [in:] A. Przyborowska-Klimczak, E. Skrzydło-Tefelska (eds.), Dokumenty..., vol. I, pp. 167-218.

${ }^{55}$ Ibidem, pp. 43-166.

${ }^{56}$ Ibidem, pp. 219-289.

${ }^{57}$ E. Dynia, Integracja europejska, Warszawa 2006, p. 43.

${ }^{58}$ Traktat o Unii Europejskiej [in:] A. Przyborowska-Klimczak, E. Skrzydło-Tefelska (eds.), Dokumenty..., vol. I, pp. 295-309.

59 E. Dynia, Integracja..., p. 49. 
began to take shape. During the meeting of the European Council on June 21-23, 2007, a compromise was reached on the Treaty of Lisbon amending the Treaty on European Union and the Treaty establishing the European Community, which was signed on December 13, 2007 and entered into force on December 1, 2009 year. ${ }^{60}$ This treaty marked a new stage in building an ever closer union between the states of modern Europe. ${ }^{61}$

The Nordic Council (SB), which is an organ of interparliamentary cooperation in the Nordic countries, also gained importance. It was created as a result of unilateral resolutions of the parliaments of the Nordic countries, and not, as is usually the case in such cases, by signing and ratifying an international agreement. The Nordic Council was established in 1952 and started operating in February 1953. It is a forum for cooperation and consultation of the parliaments of the Nordic countries. It makes recommendations to governments that are binding only in the field of foreign and defense policy. ${ }^{62}$

The later years of integration resulted in the creation of another international organization. On May 14, 1955, the heads of governments of Albania, Bulgaria, Czechoslovakia, East Germany, Poland, Romania, Hungary and the USSR signed the Warsaw Pact. ${ }^{63}$ Formally, it was created to defend against the German threat, which, according to the signatories, has increased in connection with Germany's admission to NATO. The treaty was registered with the UN secretariat as a defense alliance, acting pursuant to Art. $51 \mathrm{KNZ}$. Until the end of the 1960s, its formal platform was the Political Advisory Committee. The Warsaw Pact was not only a military structure within which the USSR controlled the armies of individual member states and thanks to which it increased its military potential, but also an area for approving political decisions and adopting declarations defining the position of the Eastern bloc countries on international problems. ${ }^{64}$

The processes of regional integration in Latin America and the Caribbean appeared with varying intensity and success since the beginning of the $19^{\text {th }}$ century.

${ }^{60}$ Treaty of Lisbon amending the Treaty on European Union and the Treaty establishing the European Community, signed at Lisbon, 13 December 2007, OJ C 306, 17.12.2007.

${ }^{61}$ M.M. Kenig-Witkowska, Charakter prawny Unii Europejskiej [in:] M.M. Kenig-Witkowska, A. Łazowski, R. Ostrihansky (eds.), Prawo instytucjonalne Unii Europejskiej, Warszawa 2019, p. 39.

${ }^{62}$ A. Zygierewicz, Wspótpraca państw nordyckich, "Biuro Studiów i Ekspertyz" 2005, np. 1115, p. 5 .

${ }^{63}$ Układ o przyjaźni, współpracy i pomocy wzajemnej między Ludową Republiką Albanii, Ludową Republiką Bułgarii, Węgierską Republiką Ludową, Niemiecką Republiką Demokratyczną, Polską Rzecząpospolitą Ludową, Rumuńską Republiką Ludową, Związkiem Socjalistycznych Republik Radzieckich i Republiką Czechosłowacką z dnia 14 maja 1955 roku, Dz. U. Nr 30, poz. 182 [Journal of Laws No. 30, item 182].

${ }^{64}$ W. Gliński, Spór o charakter i sens dalszego istnienia Układu Warszawskiego w stosunkach polsko-radzieckich w latach 1989-1999, "Studia Podlaskie" 2018, vol. XXVI, pp. 143-144. 
In the first stage, integration projects took the form of full integration, ie efforts to establish a state, usually in a sub-region (Caribbean, Colombia). After the Second World War, integration concepts changed. They were based on the formula of organizing states aimed at strengthening economic ties without losing statehood. The first efforts, especially in the 1950s and 1960s, did not bring the desired results. The intensification of cooperation between countries, which was initiated in the 1990 s, resulted in significant progress in this area. ${ }^{65}$

The first continental integration organization was the Latin American Free Trade Association (LAFTA). It was established on the basis of the Treaty establishing a free trade zone and creating the Latin American Free Trade Association. ${ }^{66}$ The founding countries were Argentina, Brazil, Chile, Mexico, Paraguay, Peru and Uruguay, and therefore only South America. At the end of the 1960s, negotiations began, which eventually led to the conclusion of a new and currently binding treaty creating the Latin American Integration Association (LAIA) ${ }^{67}$

In turn, on May 25, 1963, in the capital of Ethiopia, Addis-Ababa, 31 independent African states signed the Charter of the Organization of African Unity (OAU).$^{68}$ Conflict resolution and issues of peace, security and stability were the most important tasks for the OAU. The organization also played a part in military conflict management, deploying African troops to keep peace and organizing military ceasefire observation missions. The establishment of a mechanism in the OAU system responsible for conflict management activities was a decisive and positive step in the history of the pan-African organization. ${ }^{69}$ Successive years of international integration on the African continent led to the creation on May 26, 2001, of a new pan-African organization - the African Union (AU), ${ }^{70}$ which carries out political, military and economic tasks. ${ }^{71}$

${ }^{65}$ E. Latoszek, M. Proczek, Wstep [in:] E. Latoszek, M. Proczek (eds.), Teoretyczne koncepcje integracji regionalnej a efekty działalności ugrupowań integracyjnych w Ameryce Łacińskiej, Warszawa 2012, p. 9.

${ }^{66}$ Treaty Establishing a Free Trade Area and Instituting the Latin American Free Trade Association, signed at Montevideo, Uruguay, on February 18, 1960, UNTS 1987, vol. 1484.

67 Treaty Establishing the Latin American Integration Association, signed at Montevideo, on August 12, 1980, UNTS 1981, vol. 1329.

${ }^{68}$ Karta Organizacji Jedności Afrykańskiej z dnia 25 maja 1963 roku [in:] P. Łaski, I. Gawłowicz, E. Cała (eds.), Wybór dokumentów do nauki prawa międzynarodowego publicznego, part I, Szczecin 2002, pp. 230-240.

${ }^{69}$ B. Sidi Diallo, Afrykański regionalny system bezpieczeństwa zbiorowego $w$ świetle prawa międzynarodowego, Poznań 2018, pp. 122-123; P. Czubik, B. Kuźniak, Organizacje międzynarodowe, Warszawa 2002, pp. 54-55.

${ }^{70}$ Akt założycielski Unii Afrykańskiej z dnia 26 maja 2001 roku [in:] S. Bieleń (ed.), Prawo w stosunkach międzynarodowych. Wybór dokumentów, Warszawa 2004, pp. 479-488.

${ }^{71}$ B. Ndiaye, Od Organizacji Jedności Afrykańskiej do Unii Afrykańskiej, "Forum Politologiczne" 2004, vol. 1, p. 91. 
The following years in the history of international relations focused on concluding agreements aimed at taking protective measures and ensuring international security. ${ }^{72}$ The Conference on Security and Cooperation in Europe (CSCE), established in 1975, turned out to be a form of such cooperation. The adoption of the final act of the CSCE resulted in the creation of the European security system (including the improvement of relations between the countries of Western Europe and those belonging to the Eastern Bloc). ${ }^{73}$ The final act regulated virtually all areas of international relations - from cooperation in the field of economy, science, trade and the natural environment to security issues (political, scientific and technical, environmental and humanitarian). ${ }^{74}$

In the 1980s, the process of enlarging the CSCE was also extended to military issues, and expanded to include an extensive "human dimension", as well as economic and environmental issues. ${ }^{75}$ Initiated by the meeting at the "summit" in Paris in November 1990, institutionalization resulted in the creation of permanent CSCE bodies, and then allowed the transformation of the CSCE into the Organization for Security and Cooperation in Europe (OSCE) on January 1, 1995, ${ }^{76}$ the purpose of which was to prevent the emergence of conflicts in Europe. ${ }^{77}$

Due to the significant differences and internal antagonisms, integration processes in Asia run with great problems. They are hampered by the lack of a regional organization of cooperation (this is the only continent, apart from Australia and Oceania, where such an organization has not been established). Integration takes place in subregions and is not coordinated by any center. Integration organizations generally do not cooperate with each other. It is worth mentioning here the Gulf Cooperation Council (GCC), ${ }^{78}$ which has a complex legal basis. The main treaty

${ }^{72}$ Akt końcowy Konferencji Bezpieczeństwa i Współpracy w Europie z dnia 1 sierpnia 1975 roku [in:] A.D. Rotfeld, From Helsinki to Madrid.Conference on Security and Co-operation in Europe 1973-1983. Od Helsinek do Madrytu. Dokumenty Konferencji Bezpieczeństwa i Wspótpracy w Europie 1973-1983, Warszawa 1983, pp. 110-203.

${ }^{73}$ Z. Lorenc, Funkcje Organizacji Bezpieczeństwa i Wspótpracy w Europie w ksztaltowaniu bezpieczeństwa, “Obronność. Zeszyty Naukowe” 2016, No. 3(19), p. 186.

${ }^{74}$ R. Zięba, Funkcjonowanie paneuropejskiego mechanizmu bezpieczeństwa KBWE/OBWE, "Studia Europejskie" 1998, No. 3, pp. 85-86.

75 Z. Lorenc, Funkcje..., p. 190.

${ }^{76}$ Deklaracja szczytu budapeszteńskiego ku prawdziwemu partnerstwu w nowej erze z dnia 6 grudnia 1994 roku [in:] A. Przyborowska-Klimczak, E. Skrzydło-Tefelska (eds.), Dokumenty..., vol. I, pp. 97-100; R. Zięba, Funkcjonowanie..., p. 85.

77 The name was changed from the Conference on Security and Co-operation in Europe to the Organization for Security and Co-operation in Europe on January 1, 1995, on the basis of a decision taken at the meeting of the Heads of State or Government of the CSCE states in Budapest on December 6, 1994. See E. Dynia, Integracja..., p. 231.

${ }^{78}$ Karta Rady Współpracy Państw Zatoki Perskiej z dnia 25 maja 1981 roku, http://www.gccsg.org/en-us/AboutGCC/Pages/Primarylaw.aspx [accessed on 22.08.2019]. 
is the GCC Charter, while the second act creating this organization is the Economic Agreement between the states of the Persian Gulf Cooperation Council of December 31, 2001. ${ }^{79}$

In the following years, entities with a smaller territorial range also began to appear, such as the Commonwealth of Independent States (CIS), which was an economic, political and military union of Russia and initially 10 former union republics of the USSR. ${ }^{80}$ In its formula, the community resembled a confederation and was open to all states - members of the USSR, as well as to other states. The name "Commonwealth of Independent States" is a tautology that is not the result of being overlooked. It is an expression of the member states' integration skepticism. ${ }^{81}$ The CIS Charter unequivocally confirmed that the Community is not a state, nor does it have supranational competences ${ }^{82}$ and does not have international subjectivity, which is a necessary condition for the existence of an international organization. The CIS is therefore only an informal forum for cooperation between the post-Soviet states ${ }^{83}$ The formal signing of the CIS treaty took place in Almaty on December 21, 1991, it was signed by the leaders of 11 republics. At the same time, it was announced that the capital of Belarus - Minsk was chosen as the seat of the permanent Secretariat of the CIS. ${ }^{84}$

In addition to regional organizations operating within specific areas of the world, there are also those that are focused on specific assumptions or specific interests. Such entity is the Organization for Economic Co-operation and Development (OECD), established under the Convention on the Organization for Economic Co-operation and Development of December 14, 1960. ${ }^{85}$ It began operating on September 30, 1961. ${ }^{86}$ The OECD was established in place of the Organization

${ }^{79}$ Economic Agreement between the states of the Gulf Cooperation Council of 31 December 2001, https://www.gmco.int/Dokuments/Economic\%20Agreement.pdf [accessed on 22.08.2019].

${ }^{80}$ Z.J. Winnicki, Ustrój polityczno-administracyjny Republiki Białoruś - zarys problematyki [in:] B.J. Albin, W. Baluk (eds.), Europa Wschodnia - dekada transformacji. Białoruś, Wrocław 2004, p. 67.

${ }_{81}$ P.J. Szewczyk, Euroazjatycka Unia Gospodarcza. System instytucjonalny i prawny, Toruń 2018, p. 13.

${ }_{82}$ Art. 3(1) Porozumienia o utworzeniu Wspólnoty Niepodległych Państw z dnia 21 grudnia 1991 roku, "Eurazja" 1994, No. 1-2, vol. 2, p. 3.

${ }^{83}$ W. Czapliński, Zmiany terytorialne w Europie Środkowej i Wschodniej. Ich skutki międzynarodowoprawne (1990-1992), Warszawa 1998, p. 35.

${ }^{84}$ R. Demjaniuk, Priorytety państw członkowskich i układy regionalne w ramach Wspólnoty Niepodległych Państw, "Zeszyty Naukowe Uniwersytetu Przyrodniczo-Humanistycznego w Siedlcach. Seria: Administracja i Zarządzanie” 2011, No. 89, p. 164.

${ }^{85}$ Konwencja o Organizacji Współpracy Gospodarczej i Rozwoju z dnia 14 grudnia 1960 roku [in:] A. Przyborowska-Klimczak, E. Skrzydło-Tefelska (eds.), Dokumenty..., vol. I, pp. 123-128.

${ }^{86}$ E. Synowiec, Organizacja Wspótpracy Gospodarczej i Rozwoju [in:] S. Parzymies, Europejskie struktury wspótpracy. Informator, Warszawa 2000, p. 124. 
for European Economic Cooperation (OEEC) established in 1948. The reason for the transformation of the OEEC into the OECD was the United States' desire to maintain the relative economic unity of Western Europe, split into two blocks as a result of the establishment of the EEC and EFTA. The OECD was to include both EEC and EFTA member states, as well as the United States and Canada. ${ }^{87}$ The aim of this organization is, inter alia, achieving the highest possible economic growth, employment and a rising standard of living in Member States while maintaining financial stability and contributing to the development of the global economy. ${ }^{88}$

\section{CONCLUSION}

Today, the activity of international organizations around the world is an immanent feature of international relations in comparison with previous epochs. These entities are a platform for the exchange of views where different, often opposing concepts and interests clash, and at the same time an instrument through which the foreign policy objectives of individual states and interstate groups are realized. It seems appropriate to say that international organizations constitute the second channel - next to the diplomatic channel - in which political contacts take place. These entities are a modern and the most developed form of international cooperation. They play an important role in international relations, as evidenced by the appointment of departments of international organizations in ministries of foreign affairs, as well as actions taken by governments to fill positions in international organizations by their own citizens or citizens of allied countries. ${ }^{89}$

\section{THE HISTORY OF THE FORMATION \\ OF INTERNATIONAL ORGANIZATIONS IN THE WORLD}

\section{Abstract}

The formation of an international organization is a process which stems from the need to act at a given time and in given conditions that occur in a specific environment. An organization is established when a group of subjects of international relations realizes the need for a fully permanent and systematic cooperation in order to implement agreed tasks and competences. Interest in such activity arises when the common need or threat is of such nature and magnitude that individual entities cannot cope with them alone, or they do

${ }^{87}$ E. Pawlak, A. Malkowski, Przeglad organizacji..., p. 133.

${ }^{88}$ Z.M. Doliwa-Klepacki, Encyklopedia.., 1975, s. 415; K. Kot-Majewska, Rola OECD w międzynarodowej wspótpracy rozwojowej [in:] E. Latoszek, M. Proczek (eds.), Polityka rozwojowa. Rola organizacji międzynarodowych w zwalczaniu ubóstwa na świecie, Warszawa 2013, p. 136.

89 R. Bierzanek, J. Symonides, Prawo międzynarodowe publiczne, Warszawa 1997, p. 290. 
it ineffectively. An international organization is not created for cyclical reasons for a short, strictly defined period of time, but for the purpose of permanent cooperation based on the mutual interests of all its members.

Keyw ords: genesis, history, entity, international organization 